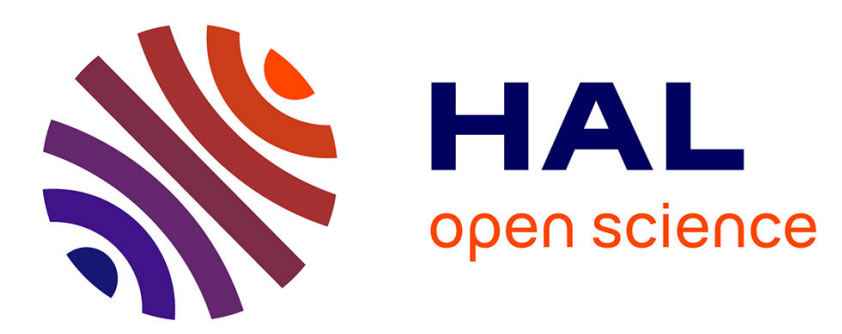

\title{
Innovation and Employment Effects in Services: A Review of the Literature and an Agenda for Research
} Faridah Djellal, Faïz Gallouj

\section{To cite this version:}

Faridah Djellal, Faïz Gallouj. Innovation and Employment Effects in Services: A Review of the Literature and an Agenda for Research. Service Industries Journal, 2007, 27 (3-4), pp.193-213. halshs01133194

\section{HAL Id: halshs-01133194 \\ https://shs.hal.science/halshs-01133194}

Submitted on 18 Mar 2015

HAL is a multi-disciplinary open access archive for the deposit and dissemination of scientific research documents, whether they are published or not. The documents may come from teaching and research institutions in France or abroad, or from public or private research centers.
L'archive ouverte pluridisciplinaire HAL, est destinée au dépôt et à la diffusion de documents scientifiques de niveau recherche, publiés ou non, émanant des établissements d'enseignement et de recherche français ou étrangers, des laboratoires publics ou privés. 
Published in The Service Industries Journal DJELLAL F., GALLOUJ F., (2007), Innovation and Employment Effects in Services: a Review of the Literature and an Agenda for Research, The Service Industries Journal, April, vol. 27 n $^{\circ}$ 3-4, p. 193-213.

\title{
Innovation and Employment Effects in Services: a Review of the Literature and an Agenda for Research
}

\author{
FARIDAH DJELLAL and FAÏZ GALLOUJ* \\ (Forthcoming in the Service Industries Journal, 2007)
}

\begin{abstract}
This article addresses the difficult question of the relationship between innovation and employment. Its main objective is to re-examine the literature on innovation in services in the light of the employment issue. In particular, it attempts to assess to what extent and in what way this question is implicitly or explicitly addressed in the literature or deserves to be introduced into it. In pursuit of these objectives, the national and international literature is reviewed and a research agenda proposed. The following three topics are explored in succession: 1) technologist approaches and the employment question; 2) the question of employment in service-based approaches; 3) innovation by services and employment.
\end{abstract}

Key words : services, innovation, employment

\section{INTRODUCTION}

The question of the relationship between technical change and employment is an old and fundamentally complex issue, on both the theoretical and empirical levels, regardless even of the problem of the sector concerned [for a survey, cf. Freeman and Soete, 1987; Petit, 1995; Vivarelli, 1995]. Behind it lies a multiplicity of contradictory causalities, both direct and indirect. Consequently, it cannot be tackled satisfactorily through a limited number of general mechanisms or at a single level of analysis, whether micro, meso or macroeconomic. The debates on 'compensation theory' (which states that market forces are able automatically to compensate for the job losses caused by a 'labour saving' innovation ${ }^{1}$ ) give some idea of the complexity of the mechanisms at work. The web of interrelationships is made even more difficult to untangle by the fact that variables other than innovation, such as demand, institutional change etc., affect the growth of employment in services. It is hardly surprising, therefore, as Vivarelli and Pianta [2000] point out, that today's neo-Schumpeterian

\footnotetext{
* CLERSE and IFRESI-CNRS. Faculty of Economics and Social Sciences, University of Science and Technology of Lille (USTL), Cité scientifique, 59655 Villeneuve d'Ascq Cedex, France. Email : Farida.Djellal@univ-lille1.fr, Faiz.Gallouj@univ-lille1.fr

${ }^{1}$ Such compensation is generally regarded as operating through the following diverse mechanisms: the development of new machines, price reductions, new investment, reductions in wages, increases in earnings, the development of new products (cf. Vivarelli, 1995; Petit, 1995).
} 
economics of innovation has avoided this question [with the notable exception of the studies by Freeman, Clark and Soete, 1982 and Freeman and Soete, 1987]. It is even less surprising that it is generally ignored also in studies of innovation in a sector that poses many other interesting and difficult theoretical problems (particularly those raised by the definition, measurement, and modes of organisation and appropriation of innovation and $R \& D)$.

Thus although the service sector is acknowledged as the main source of new jobs in modern economies, too little work has been done on the link between innovation and employment in this sector. This lack of interest in an important and long-standing theoretical question can be interpreted in different ways. Firstly, given that the economic literature has long underestimated innovation in services, it is hardly surprising that it has also underestimated and neglected its effects on employment. Secondly, Engel's law and the law of productivity have provided satisfactory theoretical arguments to explain the growth in services and of employment in services [Fourastié, 1949; Baumol, 1967; Bell, 1976]. After all, the demand for and consumption of services increase in economies in which earnings are rising, and the low rate of productivity growth in services leads to an increase in employment. Thus the main theories of growth in services [for a survey, see Delaunay and Gadrey, 1987 ; Bancel-Charensol et al., 1999] exclude the argument of innovation in services (or limit themselves to noting the low level of innovation in the sector) as a way of explaining the ineluctable shift from an industrial economy to a service economy. From this point of view, the service economy constitutes, in a way, a challenge to the Schumpeterian thesis of 'waves of creative destruction' since, in the course of the deindustrialisation process in contemporary developed economies, service organisations that innovate little have replaced industrial firms. Finally, those studies which, particularly in the USA, have sought to denounce the low quality of the jobs generated by the service economy have also helped, in their way, to block out the question of the link between innovation and employment. After all, when it comes to job creation, the service society is said to be nothing more than 'a society of servants', a 'hamburger society', a 'bad jobs society' that produces what are sometimes known as 'McJobs' [Bluestone and Harrison, 1986; Cohen and Zysman, 1987; Thurow, 1989; Mahar, 1992]. It is unlikely that such a society would encourage innovation.

Our purpose in this article is to revisit studies of innovation in services and innovation by services and to do so in the light of the employment question. Those focusing on innovation in services are often divided into two separate groups [Gallouj, 1994], differentiated by their analytical approach. The first group is made up of studies which, in essence, reduce innovation in services to the adoption of technical systems provided by industrial suppliers. Innovation here is defined solely in terms of its technological manifestations. The second group, which takes the opposite stance, includes those studies that highlight in particular the non-technological forms of innovation. These approaches, denoted by the terms 'technologist' and 'servicebased' respectively, pose the question of the relationship between innovation and employment in services in very different ways. However, there is another perspective that is also interesting and important, namely that of innovation by rather than in services, which makes it possible to consider the employment question in different terms. 
This article seeks to assess to what extent and in what form the employment question is implicitly or explicitly addressed or deserves to be introduced into the three groups identified above. Thus our aim is to explain (in a very exploratory way at this stage), whether at the level of the firm, sector or economy as a whole, the way in which the question of employment is linked (or can be linked) to innovation in and by services. In pursuit of this objective, we review the national and international literature and propose a research agenda. In doing so, we raise many more questions than we provide answers. The following three topics are explored in succession: 1) technologist approaches and the employment question; 2) the question of employment in service-based approaches; 3 ) innovation by services and employment.

\section{THE QUESTION OF EMPLOYMENT AT THE HEART OF TECHNOLOGIST APPROACHES}

Those studies that equate innovation in services with technological innovation (as adopted by services) are by far the oldest and most numerous, which to some extent has contributed to an overestimation of the technological dimension or, more precisely, to an underestimation of other aspects of innovation in services. Over and above theoretical interpretations (particularly the hypotheses associated with the concept of the production function, in which process innovations play a central role), the main argument in favour of such an approach is that service industries are becoming increasingly technology and capital-intensive, which has implications for economic variables as important as productivity and employment.

For convenience's sake, these technologist studies can be divided into three groups of uneven size (cf. Figure 1), which can be distinguished from each other by the extent of their theoretical ambition and the type of technological innovation they prioritise. The first group focuses on the consequences of the introduction of technical systems in service companies or industries (impact assessments). In this article, we will distinguish such analyses of the impacts of NICTs from more general analyses of the impacts of technological innovations of any kind. The second group contains only one study (Barras' reverse life cycle model), the aim of which is to develop a theory of innovation in services. The last group consists of studies that draw on evolutionary theory and seek to delineate innovation trajectories in services. Only the first two groups give explicit consideration to the question of employment. Although the initial taxonomic approaches (those of Pavitt or Soete and Miozzo) do not explicitly tackle this question, one can take the view that it is implicitly present or could be introduced to some extent by examining the employment implications of various forms of innovation and the type of trajectories outlined.

\section{INSERT FIGURE 1 : INNOVATION IN SERVICES AND EMPLOYMENT : A SURVEY}

\section{The Impact of Information Technologies on Employment in Services}

A considerable proportion of the literature on innovation in services is concerned with the economic consequences of the expansion of the informational paradigm and its manifestations at the micro, meso and macroeconomic levels [Petit, 1988, 1989, 
1990 ; Cossalter and Hézard, 1983 ; Tremblay ; 1989 ; Mayère, Monnoyer et al., 2001 ; Djellal, 2002]. For simplicity's sake, it will be assumed that the expansion of this paradigm can be described by means of two models of innovation (which succeed each other but may overlap): centralised or mainframe computer systems, on the one hand, and decentralised computer systems and networks, on the other. One convenient way of summarising if not the findings then at least the main general questions addressed in these numerous studies is to construct a 'matrix' that combines these two models with a set of economic variables, such as employment, skills and work organization, productivity, the tradability of the service 'product' and its nature (or quality). Thus the main theoretical questions raised can be formulated as follows: what consequences does the introduction of each of these two innovation models have for employment, skills, productivity, tradability and quality in service firms and industries?

The centralized or mainframe model is said to have a positive effect on productivity and tradability but a negative impact on employment and skill levels. This model of innovation does not seem to have any particular influence on the quality of the service provided. It equates to the computerisation of back-office functions and its primary objective is to reduce the cost of service delivery through the standardisation of tasks and the exploitation of economies of scale.

The decentralized or network model, for its part, is said to have positive effects on employment, skill levels and tradability and possibly also on productivity and quality. This second model of innovation brings about fundamental changes in front-office functions. It gives rise to economies of scope and reduces routine tasks in favour of sales and advisory activities, which generate more value added.

It should be noted that many statistical studies [e.g. Licht and Moch, 1999 ; Van Ark, 1999 ; Navarro, Camacho and Rodriguez, 2001] have concentrated on analysing the relationship between innovation and information technologies, on the one hand, and productivity, on the other, without concerning themselves directly with the question of employment in services. The aim of these analyses is essentially to invalidate or confirm what is now called Solow's paradox.

These studies provide neither definitive answers nor findings but rather hypotheses. Whatever the model of innovation under consideration, a significant proportion of the literature is concerned to present (in the case of a given firm, activity or group of activities, or even for the whole of the service sector) one, several or all of these theoretical hypotheses and their mechanisms, to compare them with reality and to attempt to interpret any discrepancies that might emerge.

Irrespective of the model under consideration, the question of innovation in services can be approached from the perspective of its consequences for other, qualitative aspects of employment. Enquiries might be made into its consequences for the gender composition of employment. Some studies [Appelbaum, 1987 ; Webster, 1996] have suggested that the impact of innovation on employment is gender-biased. Appelbaum [1987] examines the way in which innovation changed the employment structure in the insurance industry in such a way that functions that had previously been male preserves became feminised [cf. also Webster, 1986]. 
Other interesting questions are, to the best of our knowledge, little discussed in the literature, in particular the consequences of innovation in services for what Devetter [2001] calls temporal availability for work, which could be extended to become spatio-temporal availability for work. Some forms of technological or organisational innovation in services encourage or give rise to various forms of part-time working and working time commingled with domestic time and various forms of labour mobilisation in atypical physical or temporal spaces: the home in the case of teleworking and the use of mobile telephony, portable computers and the Internet. The example of teleworking, it should be noted, is a particular one, since it can be considered both as an organisational innovation within a service firm and as a consequence of innovation (introduction of IT systems) that impacts on the nature of employment.

This last observation clearly suggests that, if the links between NICTs, services and employment are to be captured in all their complexity, NICTs cannot be regarded simply as an exogenous factor (impact assessments). There is no doubt, after all, that NICTs are becoming increasingly endogenised in the service economy. Consequently, the behaviour of service firms when adopting these NICTs is no longer the sole focus of attention. Firms themselves may be playing an increasingly active role in the production and diffusion of these technologies, and innovation in services frequently involves the hybridisation of NICTs and some form of organisational engineering, that is the design and development of organisational formats and methods [Djellal et al., 2003]. This endogenisation of NICTs is providing the impetus for new products and services, new forms of demand, new activities and new markets and, consequently, new jobs [Petit and Soete, 2001; Hamdouch and Samuelides, 2002].

\section{The Impact of Technological Innovation (in all its Forms) on Employment in Services}

Drawing on Community Innovation Surveys (CIS), a small number of recent statistical studies [for example, Evangelista, 2000a ; Evangelista and Savona, 2003 ; Nählinder and Hommen, 2002 ; Jammandreu, 2003 ; Peters, 2004] have sought to measure the effects of innovation on employment and skills in services.

The Italian version of CIS 2, carried out in 1997 for the period 1993-1995, gathered data on the impacts of innovation on total employment in firms, first in a general way (the question asked being: has the introduction of innovation led to 1) an increase in employment; 2) a reduction in employment; 3) no impact on employment?) and then breaking the impact down into three skill levels: 'high, average and low'. The questions and the corresponding data are not associated with each of the types of innovation taken into account in the questionnaire (namely, the creation of a new service, the improvement of an existing service and the introduction of a new process). Thus the responses obtained are net 'results' (of the sum of the various effects of innovation). Analysing this survey (which provides a sample of 6000 firms), Evangelista [2000a] finds that innovation has an overall positive effect on employment in services. This positive effect is particularly pronounced in the case of very high-skill jobs, while the labour-saving effects of technical change impact mainly on the least skilled segments of the labour force. The survey also shows that the employment effect of innovation varies by size of firm. In large firms, innovation has a labour-saving effect (impacting mainly on low-skill jobs), whereas in small firms the employment effect is positive. 
In their study of knowledge-intensive services (KIS), Nählinder and Hommen [2002], who also draw on the second $\mathrm{CIS}^{2}$, confirm this tendency in the case of Sweden. Thus innovations in such services are said to be positively correlated with both a growth in employment and a rise in skill levels (the labour-using and upskilling effects of innovation). These results, it should be noted, are not sufficient to call into question the frequently stated hypothesis that services essentially create low-skill jobs. After all, what is being examined here is a very particular relationship, and knowledgeintensive services are not representative of services as a whole in this regard. Given their nature and their particular focus, they tend to recruit high-skill workers (regardless of the relationship to innovation, i.e. even for routine transactions). Furthermore, their activities (again, whether or not they are innovative) affect the quality and quantity of jobs in other sectors (cf. section 3).

In the case of Germany, Peters [2004] draws on $\mathrm{CIS}^{3}{ }^{3}$ in an attempt to assess the impact on employment of product and process innovations. This study differs from the previous ones in that these two types of innovations are not regarded as homogeneous categories. Peters' analysis identifies two different types of product innovation, using the degree of novelty (for the market and for the firm) as the distinguishing criterion, and two types of process innovation (firstly, rationalisation technologies and then other process innovations that do not have rationalisation as their objective but rather improvements in quality, adherence to regulatory requirements, etc.). The econometric analysis indicates that product innovations (whether new to the market or imitations, there being no significant difference between the two) have a positive net impact on employment at the level of the firm. This result, which holds true for both manufacturing and services, contradicts the traditional hypotheses that state that innovations involving products new to the market generate more jobs than innovations based on imitation. Process innovations (particularly those intended to bring about rationalisations) have negative effects on employment in manufacturing. On the other hand, during the period under investigation, this type of innovation does not seem to have led to any significant reduction in employment in services.

The statistical studies outlined above, however useful and interesting they may be, should not tempt us into forgetting the numerous methodological problems that reduce their significance. After all, the data from the Community innovation surveys were gathered on the basis of the indicators specified in the Oslo Manual [OECD, 1997]. However, these indicators are restrictive [Djellal and Gallouj, 1999]. They are concerned solely with technological innovation, which is only one of the elements of innovation in service firms and organisations.

Another problem with this type of statistical analysis lies in the definition of competence or skill (and hence in the evaluation of the positive or negative evolution of skill levels within a firm). It is likely that the surveys tend to underestimate the positive impacts of innovation on skill levels. The instructions in the Canberra Manual [OECD, 1995], which state that only those employees with a tertiary-level

\footnotetext{
${ }^{2}$ In Sweden the CIS2, which covers the period 1994-1996, provided a sample of 743 service firms (including 140 providing knowledge-intensive services).

${ }^{3}$ CIS3 was carried out in Germany in 2001. It covers the period 1998-2000 and provides a sample of 2200 firms in both manufacturing and services.
} 
qualification as defined in the International Standard Classification of Education (ISCE) [Unesco, 1976] should be regarded as high-skilled, do not seem to be satisfactory in this regard.

The question of the distinction between product and process innovation is important here, since in theory these two forms of innovation have fundamentally different impacts on employment. After all, process innovation in its traditional meaning involves the substitution of capital for labour. It therefore has a labour-saving effect, leading to job losses. Product innovation involves the introduction of new qualities into the market and hence generating new demand. It helps firms to conquer new markets or, in other words, to increase output and hence recruitment. Consequently, it is labour using and leads to job creation. According to Katsoulacos [1984], it is this succession of periods dominated by product innovation or process innovation that explains fluctuations in unemployment. Even in manufacturing industry, however, this distinction must be used with caution. Thus the description of an innovation as a product or process innovation does not reflect an intrinsic technical characteristic. The nature of an innovation may depend on how it is used. In the capital goods sphere (machine tools, for example), a product innovation for one sector (the manufacturing sector) generally becomes a process innovation for another sector (the one that adopts or uses it), leading to different employment effects for the same technical system.

In services, this distinction is difficult to put into practice. If the non-technological forms of innovation (a high share of which are probably non-technological product innovations, such as financial or insurance products - cf. section 2) are excluded, it is likely that the econometric regressions carried out would place greater emphasis to process innovations (technical systems introduced into the process of service provision). Moreover, a less materialist and technologist concept of process innovation (methodological innovation in consultancy, for example) may, in certain cases, obscure the link between innovation and employment, since methodological innovation may have different objectives: to save time by rationalising and coordinating actions and reducing uncertainties ('process effect'), as well as giving the 'service product' a framework or even adding functionalities or qualities to a product (a home delivery process, for example). In this case, it is more the 'product effect' that comes into play.

It is also on this problem of the distinction between product and process innovation that Barras' reverse life cycle model stumbles when he investigates the employment effects of the various forms of innovation.

\section{The Reverse Cycle Model and the Employment Question}

Barras [1986, 1990] developed a simple and thought-provoking model that constitutes not a theory of innovation in services (as the author claims) but rather a theory of the diffusion to services of technological innovation derived from manufacturing industry.

Barras describes the innovation cycle in services as the reverse of the traditional industrial cycle formalised by Abernathy and Utterback [1978]. This reverse cycle, which is generated by the various waves of computerisation (mainframes, minicomputers, then microcomputers and networks), consists successively of an 
incremental process innovation phase, a radical process innovation phase and a product innovation phase. The innovation does not lie in the technical systems themselves (which constitutes an important advance over most 'impact studies') but rather in the changes caused by the introduction of these systems, which take effect through the implementation of various types of learning process.

The incremental process innovations emerge in organisations' back-offices. They are aimed at improving efficiency and cutting costs. They include, for example, the storing on computers of insurance policies and the computerisation of personnel and wage records. In this first phase, the reverse cycle is characterised by a form of technical progress that is labour-saving (reduction in size of workforce) and capitaldeepening (increase in the volume of capital). In service industries in which demand is rising sharply, the labour-saving bias of the technical progress may be concealed. However, as Barras [1986] notes, it is in those industries in which the market is saturated or even shrinking that the tendency to introduce labour-saving technologies is greatest.

The radical process innovations emerge in the second phase of the cycle. They mainly affect front-office functions and they are aimed more at improving service quality. Examples include the computerised management of housing waiting lists in town halls, the registration of policies 'on line' in the offices of some insurance companies, computerised bookkeeping in accountancy firms and the installation of ATMs in banks. Improvements in quality help to expand markets to some extent. In the second phase of the cycle the 'direction or form' of the technical change, that is its impact on the factors of production, is different. The technical progress (in net value terms) is more neutral with regard to labour and it has an effect that is as much capital widening (increase in the quality of the capital) as capital deepening (increase in the volume of capital).

Product innovations are still relatively rare, for the moment at least. They should increase in parallel with the development of a public informational infrastructure able to harness the capabilities of the enabling technologies. Home banking is the best illustration of this. However, there are also new services, still at the experimental stage, such as interactive and completely computerised auditing and accounting procedures in auditing firms or the entirely 'on line' services being introduced by insurance companies. These innovations are aimed less at improving efficiency or differentiating products; their purpose rather is the conquest of new markets. Thus this product innovation phase has a positive effect on both output and employment. It is associated with a form of technical progress that is simultaneously capital widening (increase in quality) and capital saving or, in other words, labour using.

Thus Barras' reverse product cycle is also an employment cycle: in service industries, innovation begins by destroying jobs before creating them.

In reality, the reverse cycle model and its implications for employment founder on its particular concept of the product and of the distinction between product and process. The difficulty inherent in considering innovation in services in terms of the traditional distinction between product and process does not elude Barras. He recognises that, given the specificities of services, 'the product and the process of supplying it are inextricably linked'. Nevertheless, he retains this dichotomy, justifying it as follows: 
'... The more service innovations become radical [this would be the case, for example, with home banking and shopping], the more reasonable it is to identify the improvements (that result from them) in the provision of the service as "new services"”.

Furthermore, the forms of innovation considered by Barras - whether product or process - are technological innovations. Thus a radical 'product' innovation is a new service made possible by the technology. A process innovation leaves a service unchanged but delivered in a different way by means of a new technology that improves efficiency (incremental process innovation) or quality (radical process innovation). Some forms of innovation - important ones, in our view - are excluded from Barras' model, although it can reasonably be hypothesised that, all things being equal, they generate significant labour-using effects. This applies in particular to product innovations, such as the introduction of new financial products or new insurance policies in the banking or insurance sectors, for example (cf. section 2). Thus the technological bias of Barras' reverse cycle introduces bias into analyses of the impacts of innovation on employment.

\section{The Sectoral Taxonomic Approaches}

On the face of it, approaches based on sectoral taxonomies have the advantage of shifting the analysis to the sectoral level, which in turn makes it possible to capture certain 'compensation' phenomena more clearly. The taxonomic approaches that draw on Pavitt's taxonomy are not concerned explicitly with the impacts of the various innovation trajectories on employment. Thus in the taxonomy developed by Soete and Miozzo [1990], for example, as in Pavitt's [1984], size of firm (in terms of numbers employed) is, paradoxically, one of the taxonomy's structural determinants and not a variable that is dependent on a firm's position on the trajectory.

However, since this taxonomy, like Pavitt's, is based on the fundamental distinction between product and process innovation, and on the relative share of each of these types of innovation in a given sector, it can reasonably be hypothesised, all other things being equal, that the sectoral trajectories in which product innovations predominate lead to job creation (labour-using effect), whereas those dominated by process innovations lead to job destruction (labour-saving effect). Thus in Pavitt's taxonomy, all services belong to the 'supplier dominated' category, which means that they adopt process innovations developed in other sectors. All other things being equal, therefore, innovation in services is regarded as having a labour-saving effect which, from the point of view of employment statistics, is problematic, even though compensation effects may come into play, along with factors other than innovation. Soete and Miozzo, on the other hand, make a distinction between: 1) firms dominated by suppliers; 2) large-scale physical networks; 3) informational networks and 4) specialist suppliers and science-based services. From this point of view, their taxonomy is more satisfactory, to the extent that it also introduces trajectories in which product innovation predominates. This is the case, for example, with specialist suppliers and science-based services.

However interesting they may be, these sectoral taxonomies are abstract. Evangelista [2000b] and Evangelista and Savona [2003] use a number of indicators drawn from CIS2 (previously mentioned, for Italy, for the period 1993-1995) in order to develop a 
more concrete and operational sectoral taxonomy that provides a suitable basis for statistical analysis of the relationship between innovation and employment at the sectoral level.

This taxonomy identifies three sectoral innovation models in services:

1) Technology users. This category includes the more traditional service industries, such as retailing, hotels and catering, transport, cleaning, etc. These are industries with a low propensity for innovation that are dependent on industrial suppliers of technologies.

2) ICT users. These industries are characterised by their intensive use of ICTs. They include, in particular, banking, insurance and other financial services, wholesaling, advertising, etc.

3) Science and technology (S-T) based sectors. These industries include R\&D, engineering, technical consultancy and IT services. They are industries characterised by a high propensity for innovation.

The statistical analysis of the impact of innovation on employment carried out on the basis of this taxonomy produces the following results:

1) In S-T firms, the overall employment effect of innovation (that is the introduction of new services or new processes) is positive. Furthermore, there is a significant trend towards the substitution of very highly skilled labour for low-skill labour. Thus technical change has a skill bias.

2) In ICT users, the employment effect of innovation is negative. There is also a significant skill bias. In other words, the introduction of ICTs in banks, insurance companies, postal services etc. has a job destroying effect. The recruitment of skilled workers (following the introduction of new services) is not sufficient to offset the loss of low-skill jobs.

3) Among the technology users, innovation (that is the adoption of new transport systems, for example, as well as new IT systems) has (moderate) negative effects on the volume of jobs and a (moderate) skill bias. Thus the tendency to replace less skilled with more highly skilled workers is a characteristic of the service sector as a whole.

\section{EMPLOYMENT NOT A CONCERN IN SERVICE-BASED APPROACHES}

Service-based approaches are generally divided into two groups (cf. Figure 1): 1) typological (empirical) studies that focus on different types of services ; 2) local innovation theories adapted to particular service industries. The question of employment is seldom tackled in these studies, whose primary objective is to identify any possible specificities of innovation in services, whether with regard to form, mode of organisation or historical dynamic [Gallouj, 2002a, Sundbo, 1998; Metcalfe and Miles, 2000; Tether, 2003; Howells, 2004; Windrum and Koch, 2006]. Our aim here is less to explain the results produced in the literature than to open up a number of avenues of investigation that deserve to be explored. Once again, we will concern ourselves only with those studies that deal in some way with the question of employment. 
Wheel of Retailing and Wheel of Employment, Accordion Theory of Retail Change and Accordion Theory of Employment?

Retail specialists have attempted to develop theoretical models that might shed light on the innovation dynamic in that sector. Two cyclical models (which focus on the dynamic of store formats) have met with considerable success. They are the 'wheel of retailing' model [McNair, 1958] and 'accordion theory' [Hollander, 1966]. We will briefly outline these models and then try to identify any possible implications they might have for employment.

According to McNair, innovation in store formats follows a circular trajectory in which existing formats face competition from new formats that are less expensive because they are managed in accordance with the following principles: rationalisation of equipment and fittings, severe restriction of product ranges and reduction of customer services.

Thus the forces driving the wheel of retailing can be summarised as follows:

1) All new retailing formats emerge first as discount formats. Their success is due essentially to the low prices they offer, which are made possible by a policy of restricted product ranges and services, the aim of which is to achieve high sales volumes.

2) The success of this initial format attracts competitors. In order to fight back against the new entrants into the market, the established format will tend to adopt differentiation strategies (extension of product ranges, provision of new services, improving the shopping environment), which will lead inevitably to increased operating costs and will impact on prices.

3) This trading-up phenomenon, or the 'gentrification' of the format, causes the wheel to start rotating, taking the format away from its market position as a discounter and making it vulnerable to a new entrant with a more basic, less costly format.

The 'accordion theory', developed by Hollander [1966], adopts a similar perspective in an attempt to explain the store format cycle in terms of the structure and dynamic of product ranges. It suggest there is an alternation over time between formats characterised by a wide, non-specialised product range and formats organised around a narrow, specialised product range. It is this expansion and contraction of product ranges that gives rise to the accordion image.

These local theories of retail innovation, however thought-provoking they may be, have certain limitations and have been the subject of a number of critical analyses, which cannot be debated here [cf. C. Gallouj, 2004, 2005]. They are not concerned directly with the question of employment. However, at the microeconomic level at least, if the possible compensation phenomena (particularly for the consequences in terms of the market shares of discount store formats) are not taken into account, it is probably possible to associate particular employment levels with each position on the wheel or accordion. After all, the discount formats are associated with low employment levels, while the 'gentrified' formats required higher employment levels. Similarly, in its 'narrow, specialised product range' position, the accordion reflects labour-saving formats, while in its 'wide, non-specialised product range', the accordion equates to labour-using formats. 


\section{Typologies of Innovation in Services Based on Empirical Investigations}

A number of empirical investigations have been carried out from the so-called service-based perspective with the aim of highlighting the existence of particular forms of innovation in services. These investigations are unanimous in criticising the short-sightedness of technologist approaches, which emphasise technological innovation at the expense of other forms of innovation.

Studies of this type have been carried out for various types of services: consultancy, financial services and insurance, distributive services, hotels and catering and local services, among others. The question of the link between employment and innovation is seldom explored. This is scarcely surprising, since the main thrust of the research is to examine the difficult question of the heterogeneity of innovation, which of course reflects the heterogeneity of the product. After all, the types of products (or outputs) vary considerably from one service activity to the other. Consequently, the content of product innovation differs depending on the service activity in question. The difficulty of applying the traditional definitions seems to increase with services whose medium or target is information, knowledge or individuals.

However, various hypotheses can be advanced as to the job-destroying or creating potential of the various forms of innovation highlighted in the literature, taking as a reference point the traditional distinction between product and process innovation. After all, all things being equal, that is without taking account of positive or negative compensation phenomena (cannibalisation of old products in the case of product innovations, price effects in the case of process innovations, etc.), it is generally accepted that product innovations have positive employment effects, since they extend the variety of goods and services and open up new markets. Process innovations, on the other hand, are destructive of employment (at firm level at the very least and at a given point in time), since they are aimed at improving the efficiency with which goods or services are produced and thus at substituting capital for labour. Attempts can be made to evaluate the labour-using or labour-saving potential of a number of particular forms of innovation identified in the service-based literature. In the analyses below, the main theoretical issue at stake is not, at this stage, to examine the question of the impact on employment (since we start from the hypothesis that, all things being equal, product and process innovations have positive and negative employment effects respectively) but rather to identify and designate the product and the process. The forms of innovation examined in the service-based literature cannot usually be defined either as product or process innovations (at least in the sense given to these categories in the case of the production of tangible goods), but an attempt can be made to assess which of the product or process effects seems to dominate (whether in reality or simply in conventional terms) in each type of innovation.

In the course of this analytical exercise, we will examine three typologies of innovation associated with three different service industries: 1) consultancy and, more generally, knowledge-intensive services; 2) insurance services and, more generally, financial services; 3 ) distributive services. 
Knowledge-intensive services. Drawing on the results of an in-depth empirical investigation, Gallouj [1994, 2002a] identifies three types of innovation: ad hoc innovation, new expertise-field innovation and formalisation innovation.

- Ad hoc innovation can be defined as follows: it is a solution (i.e. a package of knowledge) that sheds a certain degree of new light on a firm's problem (whether it be legal, organisational, strategic or technical in nature) but cannot necessarily be applied (in its entirety) to other situations or firms. It is, as it were, an incremental product innovation in which the product is not a tangible entity but an intellectual solution to a company's problem. Thus it can reasonably be hypothesised that, all things being equal, it is the labour-using product effect that comes into play here, since the ad hoc innovation (and this ability to produce innovative solutions) leads both to the acquisition of new customers and new orders from existing customers. Thus the assumption made here is that firms that call in consultants are not doing so in order to reduce transaction costs but rather to bridge a gap in expertise.

- New expertise field innovation denotes the accumulation of input knowledge on emerging spheres of knowledge (the Internet is a good contemporary example),with the aim of providing services (output knowledge) relating to these new spheres [Gallouj, 2002a]. By analogy with Schumpeter's categories [Schumpeter 1961], and since knowledge is both an input and an output in knowledge-intensive services, innovation in a new sphere of expertise can be said to encompass 1) new products, 2) new markets and 3) new sources of raw materials. Unlike the previous type, this type of innovation is radical. Here too, it is the labour using product effect that is clearly dominant. Innovation involving a new sphere of expertise may be reflected in the creation of new departments in existing firms or even in the establishment of new firms.

- Formalisation innovation denotes a heterogeneous set of mechanisms that can be used to sketch in the contours of the 'hazy entities' that services are, that is to give them a certain degree of materiality if not tangibility. This materiality may be achieved with the aid of two different types of mechanisms, which may be combined: 1) tangible mechanisms, for example the introduction of technical systems into the service format (these are what are generally known as process innovations); 2) intangible mechanisms: the introduction of methods, that is scripts describing the distribution of roles in the 'live theatrical performance' that is staged every time a service is delivered; the design and use of toolkits made up of analytical instruments that shape thinking and behaviour (e.g. BCG matrices); the establishment of an organisation that incorporates the intangible service.

It would be mistaken to regard this form of innovation, in contrast to the two previous forms of (product) innovation, as a process innovation, in other words, to reduce the formalisation to mere rationalisation. The impact of a 'formalising' innovation on employment is probably indeterminate or, more precisely, variable, since it is dependent on the type of formalisation carried out. Broadly speaking, tangible mechanisms could be regarded as tending to exert a 'process' effect', while intangible mechanisms tend to exert a 'product' effect. In other words, if it involves the introduction of technical systems, then the formalisation produces labour savings (process effect), but if it takes intangible forms (that seek to make the product more visible without any significant effect on the efficiency of production), then it is the 
product effect (labour-using) that dominates. In reality, however, some tangible mechanisms also generate product effects, while intangible mechanisms also produce process effects.

Insurance and financial services. The typology proposed for insurance and financial services [Gadrey and Gallouj, 1994] may at first sight seem simple and easy to interpret, since it largely separates product from process innovations, which are denoted by these same terms (cf. Table 1). However, interpretation of the typology is a more difficult exercise than it might appear at first sight. In order to facilitate the analysis, the various types of innovations are presented here separately. In reality, they are very frequently indissociable from each other, with regard both to production and effects. Thus many process and product innovations are only two facets of the same phenomenon and process and organisational innovations are often indissociable. To put it another way, the same innovation may be the locus for contradictory employment effects, which are difficult to disentangle from each other.

Nevertheless, the categories A, B and C (product-service innovation, architectural innovations, innovations based on modifications to a product or service) are certainly product innovations, albeit of a particular type, since they are intangible (new policies, new services). They form the heart of the insurance business but largely elude Barras' model [1986, 1990] which, as we have already noted (cf. section 1.3), adopts a very restrictive definition of 'new products'. Thus in theory (all things being equal), their impact on employment is of the labour-using type. On the other hand, in categories D1, D2, D3, D4 and D5 (process and organisational innovations, innovations in methods and management), it is the labour-saving process effect that is dominant. Nevertheless, it is clear that the effects of the various innovations on a firm, its business activities, skill levels, jobs etc, cannot be isolated from each other but have to be apprehended systemically.

\section{INSERT TABLE 1 : THE MAIN FORMS OF INNOVATION IN INSURANCE [GADREY AND GALLOUJ, 1994]}

Distributive services. In distributive services, Dupuis [1998] identifies the following four forms of innovation: 1) concept innovation, 2) innovation relating to flows, 3) organisational innovation and 4) architectural innovation.

Concept innovation can be defined as the combination of a distribution format and differentiating positioning. Thus it is the product effect that dominates and hence, at the microeconomic level, the labour-using effect.

Innovations relating to flows seek to reduce costs by optimising various types of flows, whether they be physical, financial or informational. Similarly, organisational innovations (whether internal or external) are intended to improved the functioning and profitability of networks. If the effects of any possible compensations are neutralised, innovations relating to flows and organisational innovations essentially have a labour-saving effects. 
Architectural innovations, finally, are defined as a coherent combination of the preceding types of innovations (concept, flows-related and organisational). Thus their effect on employment is difficult to determine in advance, since it is the combination and the result of labour-saving and labour-using effects.

\section{INNOVATION BY SERVICES AND THE EMPLOYMENT QUESTION}

Knowledge-intensive services (including consultancy) merit particular attention because their link with employment must be considered at two levels. It is necessary, firstly, to examine the employment effects of innovation in this sector. In this regard, knowledge-intensive services are no different from other service industries. They too have been analysed from the various perspectives outlined above. This having been done, it is necessary to examine the employment effects of knowledge-intensive services on other sectors, whether manufacturing or services.

Knowledge-intensive services are, after all, veritable machines for processing and producing information and knowledge (whether scientific and technical, human or social), which are made available to clients (whether in manufacturing or service firms). They lie at the heart of what is now known as the 'knowledge economy'. Knowledge transfers and the innovations they give rise to, many of which are coproduced, make knowledge-intensive services a source of economic growth and hence of employment creation in other sectors of the economy.

Knowledge-intensive services are sometimes described as a new locus for expression of the Schumpeterian spirit of enterprise, in addition to the individual entrepreneur (Schumpeter model no. 1) and manufacturing firms' R\&D departments (Schumpeter model no. 3). This new model takes account of the collaboration that takes place between service provider and client when the latter encounters a problem (which may be technical, organisational, legal, strategic, etc.) for which a (possibly innovative) solution is to be co-produced. Knowledge-intensive services may act on their clients' products, processes, organisational structures etc. at both the concrete and symbolic levels (image, atmosphere, etc.). Consequently, these services are capable of playing an important role in what in evolutionary theory [Lundvall, 1985, 1988; Malerba, 2002] are known as (local, regional, national or sectoral) innovation systems and in the socio-economics of innovation as technico-economic networks [Callon, 1991]. Here too, analysis of their employment effects is particularly difficult.

The recent literature includes a number of studies of the role knowledge-intensive services play in innovation in their client firms. The greater share of these studies focus on the outsourcing of R\&D activities, the role of 'intermediate public agencies' in the diffusion of scientific and technical information and the role of ITC consultants in the diffusion of hardware, software and orgware [Djellal, 1995]. From a broader perspective, Bessant and Rush (1995), Hales (1997), Gallouj [2002b, 2002c], and Toivonen [2004] are concerned with consultants' contribution to technology transfer; in these studies, technology is not reduced solely to its tangible aspect nor transfer to its linear dimension. Miles et al. [1994] identify the various roles of knowledgeintensive business services, defining them as users, carriers and sources of innovation. For his part, Antonelli [1996], drawing on data from input-output tables and modelling his methodology on the physical processes of percolation analyses the role played by ICTs in improving agents' 'connectivity' (i.e. the number of connections 
established between the agents in a network) and 'receptiveness' (i.e. their capacity for absorbing information) as a result of the increased use of knowledge-intensive business services. Finally, in a study of the potential for growth and productivity gains in contemporary developed economies (which are characterised by both a high share of services and growth regimes based on successive waves of NICTs), Petit [2002] argues that two important factors relating to the service sector play a role in the exploitation of this new growth. They are, firstly, countries' ability to transform social services and services to households and, secondly, their ability to make the complex service sector a locus for innovation and a medium for change and innovation.

On the other hand, however, there are not, to the best of our knowledge (probably because of a lack of data rather than any theoretical difficulties), any statistical studies focusing on the link between the innovation generated by knowledge-intensive services and employment in their client firms. This would be an interesting line of research to explore, one that would require the use of specifically designed questionnaires. For simplicity's sake, a distinction could be made between, on the one hand, the contribution the innovation generated by knowledge-intensive services makes to quality and, on the other, their contribution to clients' productivity. When such services help to improve their clients' product or service quality, they tend to exert a labour using effect. On the other hand, when they help to improve the efficiency of processes and organisations, their effect tends to be more labour saving.

This theme of innovation by services and its relationship with employment raises many other interesting questions that merit further exploration. We will confine ourselves to simply listing them. One is the question of the place and role of human resources consultants (in the broad sense). After all, the very nature of these activities brings them into direct contact with employment issues, and it may prove interesting to examine their effects (and particularly the effects of their innovations) on both the quantitative and qualitative aspects of employment in the client firms. Another interesting question reflects an old debate on the relation and trade-off between outsourced and in-house consultancy activities. After all, it can be hypothesised that, if these activities are very effective in terms of innovation, then the possible positive employment effects in their client firms may be weakened by the negative effects (in terms of jobs for the function in question) of the tendency to substitute the use of consultants (outsourcing) for internal recruitment.

\section{CONCLUSION}

The question of innovation in services and its links with employment is a fundamental issue which, paradoxically, does not occupy the place it deserves in the economic literature. In this article, we have considered this question in an essentially programmatic way by trying to link it to the main empirical or theoretical studies of innovation in services.

The reason why relatively little attention has been paid to this question, despite the fact that it is unanimously regarded as fundamental, is that one of the variables in the link (namely the question of innovation in services) has not yet been clarified on the theoretical level. The nature and status of innovation in services remain ill-defined, which means that any attempt to analyse the implications of such innovation for employment is regarded as a risky venture. 
Nevertheless, this is a promising area of research, which is important both theoretically and in terms of public policies. It should be explored further on the micro, meso and macroeconomic levels, whether through deductive theory construction or qualitative or statistical inductive analyses. The three general research topics we have explored in this article (namely innovation in services in its technologist and service-based aspects and innovation by services) may offer an initial focus for such exploration. Another interesting area, which we have not mentioned here but which would merit specific analysis, is (innovation) entrepreneurship in services and its links with employment. After all, if the question of entrepreneurship and its links with services is not a new one, since most new startups take place in the service sector, that of entrepreneurship and its links with innovation in services has rarely been addressed.

\section{ACKNOWLEDGEMENTS}

An earlier French version of this paper benefited from comments by the participants in the $15^{\text {th }}$ International Conference of RESER, Granada (Spain), 2005.

\section{REFERENCES}

Abernathy, W. and J. Utterback (1978) Patterns of industrial innovation, Technology Review, 80, june-july, pp.41-47.

Antonelli, C., (1996) Localized knowledge percolation processes and information networks, Journal of Evolutionary Economics, 6, pp.281-295.

Appelbaum, E., (1987) Technology and the redesign of work in the insurance industry, in B. Drygulski White (ed.) Women, work and technology. Transformations, Ann Arbor: University of Michigan Press.

Bancel-Charensol, L., Delaunay, J.-C. and M. Jougleux (1999), Les services dans l'économie française, Paris: Armand Colin.

Barras, R., (1986) Towards a theory of innovation in services, Research Policy, 15, pp.161-173.

Barras, R., (1990) Interactive Innovation in Financial and Business Services: The Vanguard of the Service Revolution, Research Policy, 19, pp.215-237.

Baumol, W., (1967) Macroeconomics of unbalanced growth, American economic review, 2, pp.415-426.

Bell, D., (1976) Vers la société post-industrielle, Paris: Laffont.

Bessant, J. and H. Rush (1995), Building bridges for innovation: the role of consultants in technology transfer, Research Policy, 24, pp.97-114.

Bluestone, B. and B. Harrison (1986) The Great American Job Machine, Report for the Joint Economic Committee, December.

Callon, M., (1991) Réseaux technico-économiques et irréversibilité, in R. Boyer (ed.), Les figures de l'irréversibilité en économie, Paris: Edition de l'école des hautes études en science sociale.

Cohen, S. and J. Zysman (1987) Manufacturing Matters, New-York: Basic Books.

Cossalter, C. and L. Hezard (1983), Nouvelles perspectives de l'informatisation dans les banques et les assurances, CEREQ. 
Delaunay, J.-C. and J. Gadrey (1987), Les enjeux de la société de service, Paris: Presses de la Fondation Nationale des Sciences Politiques.

Devetter, F.-X., (2001) L'économie de la diponibilité temporelle au travail : la convention fordiste et ses remises en cause, $\mathrm{PhD}$ Thesis, University of Lille.

Djellal, F., (2002) Innovation trajectories in the cleaning industry, New Technology and Employment, 17(2), Summer, pp.119-131.

Djellal, F., Francoz, D., Gallouj, C., Gallouj, F. and Y. Jacquin (2003) Revising the definition of research and development in the light of the specificities of services, Science and Public Policy, 30/6, pp.415-430.

Djellal, F. and F. Gallouj (1999) Services and the search for relevant innovation indicators: a review of national and international surveys, Science and Public Policy, Vol. 26(4), August, pp.218-232.

Dupuis, M., (1998) L'innovation dans la distribution: ses implications dans les rapports industrie-commerce, Décision Marketing, $\mathrm{n}^{\circ}$ 15(3), pp.29-41.

Evangelista, R., (2000a) Innovation and Employment in Services : Results from the Italian Innovation Survey, in Vivarelli M. and M. Pianta (eds), The Employment Impact of Innovation : Evidence and Policy, London and New York: Routledge.

Evangelista, R., (2000b) Sectoral patterns of technological change in services, Economics of innovation and new technology, 9, pp.183-221.

Evangelista, R. and M. Savona (2003) Innovation, employment and skills in services : firm and sectoral evidence, Structural Change and Economic Dynamics, 14, pp.449-474.

Fourastié, J., (1949) Le grand espoir du XXème siècle, Paris: PUF.

Freeman, C. and L. Soete (1994) Work for all or mass unemployment? computerised technical change into the twenty-first century, London: Pinter.

Freeman, C. and L. Soete (eds) (1987) Technical change and full employment, Oxford: Basil Blackwell.

Freeman, C., Clark, J. and L. Soete (1982) Unemployment and technical innovation, London: Pinter.

Gadrey, J. and F. Gallouj (1994) L'innovation dans l'assurance: le cas de l'UAP, Research for UAP and the French Ministry of higher education, research and technology.

Gallouj, C., (2004) «Innovation et trajectoires d'innovation dans le grand commerce : une approche lancastérienne », Innovations, Cahiers d'économie de l'innovation, $\mathrm{n}^{\circ} 19$, pp.75-99.

Gallouj, C., (2005) Socio-économie de l'innovation: une application au grand commerce, Habilitation à diriger des recherches, University of Lille.

Gallouj, F., (1994) Economie de l'innovation dans les services, Paris : L'Harmattan.

Gallouj, F., (2002a) Innovation in the Service Economy : the New Wealth of Nations, Cheltenham, UK, Northampton MA, USA: Edward Elgar Publishers.

Gallouj, F., (2002b) Knowledge intensive business services : processors of knowledge and producers of innovation, in Gadrey, J. and F. Gallouj (eds), Productivity, Innovation and Knowledge in services: New Economics and Socio-Economics Approaches, Cheltenham, UK, Northampton MA, USA: Edward Elgar Publishing. 
Gallouj, F., (2002c) Interactional innovation: a neoschumpeterian model, in Sundbo J. and L. Fuglsang (eds) Innovation as strategic reflexivity, London and New York: Routledge.

Hollander, S.C., (1966) Notes on the retail accordion, Journal of Retailing, 42(2), pp.24-34.

Howells, J., (2004) Innovation, Consumption and Services: encapsulation and the combination role of services, The Service Industries Journal, Vol. 24, pp.19-36.

Jammandreu,, J. (2003) Does innovation spur employment? a firm-level analysis using Spanish CIS data, European Project «Innovation and Employment in European Firms : Microeconometric Evidence », July.

Katsoulacos, Y., (1984) Product innovation and employment, European Economic Review, 26, pp.83-108.

Licht, G. and D. Moch (1999) Innovation and Information Technology in Services, Canadian Journal of Economics, Vol. 32(2), pp.363-383.

Lundvall, B.A., (1985) Production innovation and user-producer interaction, Aalborg: Aalborg University Press.

Lundvall, B.A., (1988) Innovation as an interactive process: from user-producer interaction to national systems of innovation in G. Dosi et al. (eds), Technical change and economic theory, London: Pinter Publishers.

Mahar, M., (1992) 'Blue collar, white collar: good jobs are vanishing throughout the economy', Barron's, May, 11, pp.8-24.

Malerba, F., (2002) Sectoral Systems of Innovation, Research Policy, 31, pp.247-264.

Mayère, A., Monnoyer, M.-C., Peyrard, C. and M.F. Peyrelong (2001) Flexibilisation $d u$ travail et systèmes d'information multimédia en "juste à temps », research report for CNET.

McNair, M.P., (1958) Significant trends and developments in the post war period, in A.B. Smith (ed.) Competitive Distribution in a Free High Level Economy and its implication for the University, Pittsburg: University of Pittsburgh Press.

Metcalfe, J.S. and I. Miles (eds) (2000) Innovation systems in the service economy, London: Kluwer Academic Publishers.

Miles, I., Kastrinos, N., Flanagan, K., Bilderbek, R., den Hertog, P., Huntink, W. and P. Bouman, (1994) M. Knowledge-Intensive Business Services: Their Role as Users, Carriers and Sources of Innovation, PREST, University of Manchester.

Nählinder, J. and L. Hommen (2002) Employment and Innovation in Services: Knowledge Intensive Business Services in Sweden, Report for the final meeting and conference of AITEG, Birkbeck College, London, 18-19 april.

Navarro, J., Camacho, J. and M. Rodriguez (2001) Productive system efficiency and NICT in the European Union, $11^{\text {th }}$ RESER conference «New information technologies and service activities », Grenoble, october.

OCDE (1995) Manuel sur la mesure des ressources humaines consacrées à la science et à la technologie, Manuel de Canberra, Paris.

OCDE (1997) Principes directeurs proposés pour le recueil et l'interprétation des données sur l'innovation technologique, Manuel d'Oslo, Paris.

Pavitt, K. (1984) Sectoral Patterns of Technical Change : Towards a Taxonomy and a Theory, Research Policy, $\mathrm{n}^{\circ} 13$, pp.343-373. 
Peters, B., (2004) Employment effects of different innovation activities : microeconometric evidence, ZEW (Centre for European Economic Research), dicussion paper $\mathrm{n}^{\circ}$ 04-73.

Petit, P., (1988) La croissance tertiaire, Paris: Economica.

Petit, P., (1989) Structural Change, Information Technology and Employment : The case of France, Workshop on computation and information technology, Bard College, 13-17 june.

Petit, P., (1990) Emploi, Productivité et technologies de l'information : le cas des services, IRIS Conference, University of Paris XI Dauphine «Compétence et compétitivité », 5 april.

Petit, P., (1995) Employment and Technological Change, in P. Stoneman (ed.) Handbook of the economics of innovation and technological change, Oxford and Cambridge: Blackwell.

Petit, P., (2002) Growth and Productivity in a knowlege based service economy, in Gadrey, J. and F. Gallouj (eds) Productivity, Innovation and knowledge in services, Cheltenham, UK, Northampton MA, USA: Edward Elgar.

Petit, P. and L. Soete (eds) (2001) Technology and the future of european employment, Cheltenham, UK, Northampton MA, USA: Edward Elgar.

Rada, J., (1987) Information Technology and Services in Giarini O. (ed.), The Emerging service Economy, Oxford: Pergamon Press.

Schumpeter, J., (1961) (German first edition, 1912, French first edition 1935), Théorie de l'évolution économique, Paris: Librairie Dalloz.

Soete, L. and M. Miozzo (1990) Trade and Development in Service: a Technological Perspective, mimeo, MERIT.

Sundbo, J., (1998) The organisation of innovation in services, Roskilde: Roskilde University Press.

Sundbo, J. and F. Gallouj (1999) Innovation as a loosely coupled system in services, International Journal of Services Technology and Management, Vol. 1(1), pp.1536.

Tether, B., (2003) The Sources and Aims of Innovation in Services: variety between and within sectors, Economics of Innovation and New Technology, Vol. 12(6), pp.481-505.

Thurow, L., (1989) Towards a high-wage, high productivity service sector, Economic Washington DC : Policy Institute.

Toivonen, M., (2004) Expertise as business: Long-term development and future prospects of knowledge-intensive business services, Doctoral dissertation series, Helsinki University of Technology.

Tremblay, D., (1989) La dynamique économique du processus d'innovation : une analyse de l'innovation et du mode de gestion des ressources humaines dans le secteur bancaire canadien, $\mathrm{PhD}$ Thesis, University of Paris I.

UNESCO (1976), Classification internationale type des de l'éducation (CITE), Paris.

Van Ark, B., Monnikhov, E. and N. Mulder (1999) Productivity in services: an international comparative perspective, Canadian Journal of Economics, Vol. 32(2), pp.471-499. 
Vivarelli, M. and M. Pianta (eds) (2000), The employment impact of innovation: evidence and policy, London and New York: Routledge.

Vivarelli, M., (1995), The economics of technology and employment: Theory and Empirical Evidence, Aldershot : Edward Elgar.

Webster, J., (1996) Shaping women's work. Gender employment and information technology, London: Longman.

Windrum, P. and P. Koch (eds) (2006), Innovation in Public Services: Management, Creativity, and Entrepreneurship, Cheltenham, UK, Northampton MA, USA: Edward Elgar Publishers (forthcoming). 
FIGURE 1 : INNOVATION IN SERVICES AND EMPLOYMENT : A SURVEY

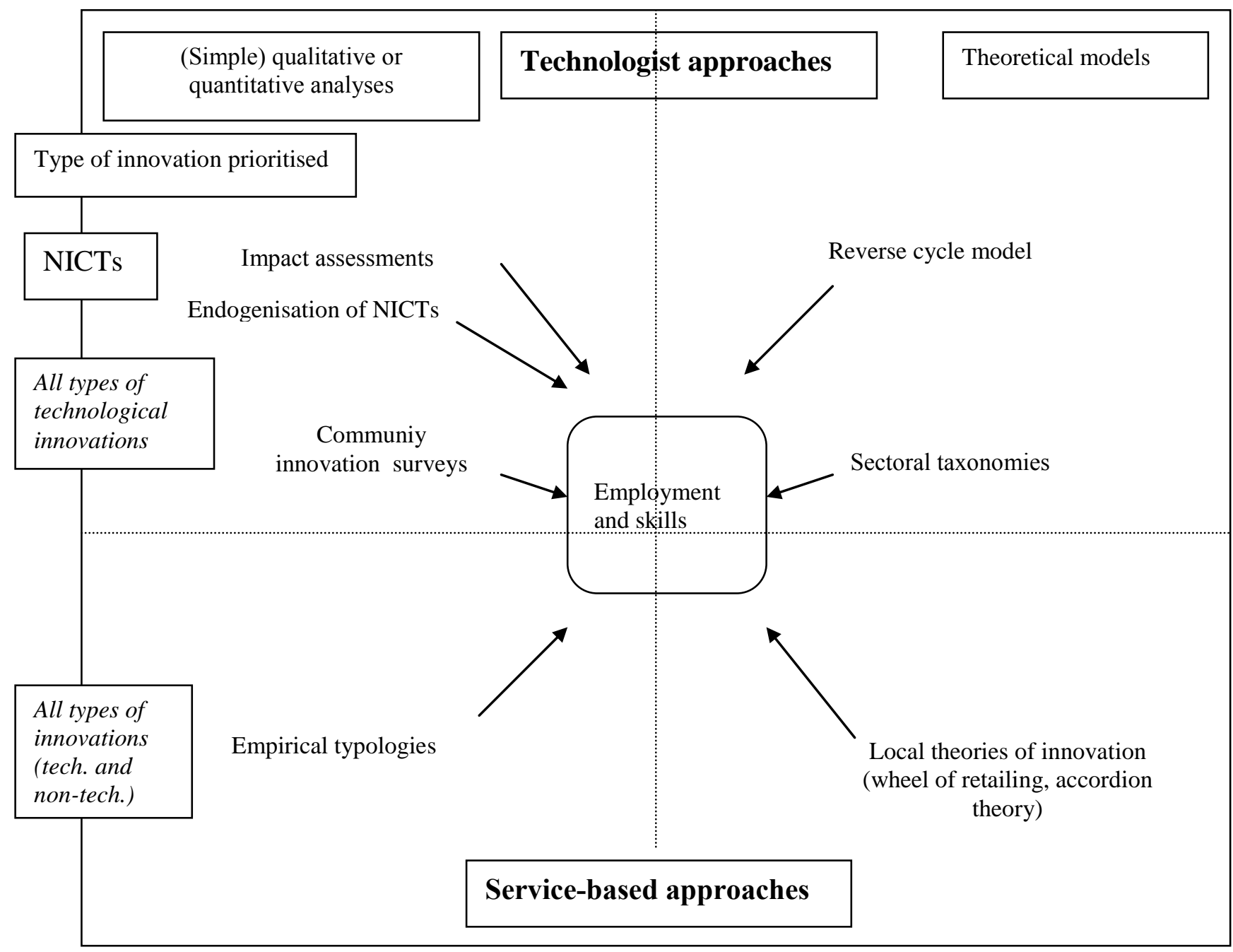




\begin{tabular}{|c|c|c|c|}
\hline $\begin{array}{c}\text { TYPES OF } \\
\text { INNOVATION }\end{array}$ & \multicolumn{2}{|c|}{ SUB-CATEGORIES } & DEFINITION \\
\hline \multirow{5}{*}{$\begin{array}{l}\text { A : } \\
\text { PRODUCT/ } \\
\text { SERVICE } \\
\text { INNOVATIONS }\end{array}$} & \multicolumn{2}{|c|}{$\begin{array}{l}\text { A1: 'Absolute' product/service } \\
\text { innovations }\end{array}$} & $\begin{array}{l}\text { New service, concept or policy for the whole } \\
\text { market }\end{array}$ \\
\hline & \multicolumn{2}{|c|}{ A2 : 'Relative' product/service innovations } & $\begin{array}{l}\text { New service, concept or policy for the } \\
\text { company concerned }\end{array}$ \\
\hline & \multirow{3}{*}{$\begin{array}{l}\text { A3 :Tailor-made } \\
\text { product/service } \\
\text { innovations }\end{array}$} & $\begin{array}{l}\text { 1) Adaptive tailor- } \\
\text { made innovations }\end{array}$ & $\begin{array}{l}\text { Adaptation of a standard policy for a particular } \\
\text { client through changes in pricing or the } \\
\text { addition of certain supplementary clauses. }\end{array}$ \\
\hline & & $\begin{array}{l}\text { 2) Fully tailor-made } \\
\text { innovations }\end{array}$ & $\begin{array}{l}\text { Design of a genuinely specific policy for a } \\
\text { given client. }\end{array}$ \\
\hline & & $\begin{array}{l}\text { 3) Cover for special } \\
\text { risks }\end{array}$ & $\begin{array}{l}\text { Cover for a new risk affecting only statistically } \\
\text { small populations. }\end{array}$ \\
\hline \multirow{2}{*}{$\begin{array}{l}\text { B : } \\
\text { ARCHITECTU } \\
\text { RAL } \\
\text { INNOVATION } \\
\text { S }\end{array}$} & \multicolumn{2}{|c|}{ B1 : Product/service bundling innovations } & Combination of existing products/services \\
\hline & \multicolumn{2}{|c|}{$\begin{array}{l}\text { B2 : Product/service unbundling } \\
\text { innovations }\end{array}$} & $\begin{array}{l}\text { Isolation of one element in a product/service } \\
\text { for sale as a separate item }\end{array}$ \\
\hline \multicolumn{3}{|c|}{$\begin{array}{l}\text { C : INNOVATIONS BASED ON MODIFICATIONS TO A } \\
\text { PRODUCT OR SERVICE }\end{array}$} & $\begin{array}{l}\text { Certain specifications and options are } \\
\text { modified, leaving the basic formula unchanged }\end{array}$ \\
\hline \multirow{5}{*}{$\begin{array}{c}\text { PROCESS AND } \\
\text { ORGANISATIO } \\
\text { NAL } \\
\text { INNOVATIONS, } \\
\text { INNOVATIONS } \\
\text { IN METHODS } \\
\text { AND } \\
\text { MANAGEMENT }\end{array}$} & \multicolumn{2}{|c|}{$\begin{array}{l}\text { D1 : Innovations introduced in support of } \\
\text { product/service innovations }\end{array}$} & $\begin{array}{l}\text { Process and organisational innovation } \\
\text { following a product/service of type A, B or C } \\
\text { and indissociable from it. }\end{array}$ \\
\hline & \multicolumn{2}{|c|}{$\begin{array}{l}\text { D2 : Innovations associated with a } \\
\text { product/service that remains unchanged in } \\
\text { terms of both formal specifications and } \\
\text { mode of delivery }\end{array}$} & $\begin{array}{l}\text { Significant change in process (technology, } \\
\text { work organisation) leaving the final service } \\
\text { unchanged }\end{array}$ \\
\hline & \multicolumn{2}{|c|}{$\begin{array}{l}\text { D3 : Innovations associated with a } \\
\text { product/service whose formal } \\
\text { specifications remain unchanged but whose } \\
\text { mode of delivery, perceived quality and } \\
\text { marketing are to be improved }\end{array}$} & $\begin{array}{l}\text { Significant change in process (technology, } \\
\text { work organisation) leaving the product } \\
\text { 'formally' identical but improved in quality }\end{array}$ \\
\hline & \multicolumn{2}{|c|}{ D4 : Formal management innovations } & $\begin{array}{l}\text { Innovations relating to financial, actuarial, } \\
\text { legal, HR management, etc. }\end{array}$ \\
\hline & \multicolumn{2}{|c|}{$\begin{array}{l}\text { D5 : Informal management innovations (ad } \\
\text { hoc or makeshift innovations) }\end{array}$} & $\begin{array}{l}\text { Differentiated from the forms outlined above } \\
\text { by their informal nature }\end{array}$ \\
\hline
\end{tabular}

TABLE 1 : THE MAIN FORMS OF INNOVATION IN INSURANCE [GADREY AND GALLOUJ, 1994] 